\title{
THE EFFECT OF AMINO ACID COMPOUNDS IN FERMENTED SOYBEANS AGAINST FIBROBLAST GROWTH FACTOR IN MICE PANCREATIC $\beta$-CELLS FIGURES
}

\section{SURYA DHARMA*, DEDY ALMASDY, DWISARI DILLASAMOLA, ROSLINDA RASYID, DIANTY DWI WAHYUNI, FADHILAH AFIFI}

Department of Pharmacy, Faculty of Pharmacy, Andalas University, Padang, Indonesia. Email: suryadharma@phar.unand.ac.id Received: 06 April 2018, Revised and Accepted: 18 May 2018

\begin{abstract}
Objective: The aim of this study is to determine the effect of the amino acid compound in fermented soybeans against fibroblast growth factor (FGF) in mice's pancreatic $\beta$-cell figures. This study was also done to know the effect of given combination of fertilized egg whites powder with tempe (Indonesian conventional food and the fermentation product of soybeans fermentation) in a dose of $7250 \mathrm{mg} / \mathrm{kg}$
\end{abstract}

Methods: All of the experimental animals pancreases were designed to be damaged by given alloxan in a dose of $150 \mathrm{mg} / \mathrm{kg}$, except for the negative control group without anything given. The experimental animals were divided into 7 groups which consist of the negative control group, positive control group, and the rests 5 group of FGF test preparation in dosages of 100; 140; 200; 300; and 425 mg/kg combined with fermented soybeans in a dose $7250 \mathrm{mg} / \mathrm{kg}$. This experiment was conducted for 21 days, observed at $7^{\text {th }}, 14^{\text {th }}$, and $21^{\text {st }}$ day. The data analysis used is a statistical test of one-way analysis of variance (ANOVA) and two-way ANOVA.

Results: The result showed a significant decrease in blood glucose levels $(\mathrm{p}<0.05)$ in mice for all treatments when compared with positive controls. From the result of the histopathologic examination, pancreatic $\beta$-cells improve utterly close to the control condition (-). In the qualitative immunohistochemical examination, there was a difference in the stained pancreatic $\beta$-cells marked by yellow density. Meanwhile, the quantitative observation did not show any improvement against normal condition control $(-)(\mathrm{p}<0.05)$.

Conclusion: The combination of egg whites and fermented soybean significantly decreased the blood glucose levels, and the occurrence of the Langerhans island cells was nearly normal.

Keywords: Amino acid, Soybeans, Fibroblast growth factor.

(C) 2018 The Authors. Published by Innovare Academic Sciences Pvt Ltd. This is an open access article under the CC BY license (http://creativecommons. org/licenses/by/4. 0/) DOI: http://dx.doi.org/10.22159/ajpcr.2018.v11i9.26475

\section{INTRODUCTION}

Diabetes mellitus (DM) is a group of metabolic disorders characterized by hyperglycemia and abnormalities in carbohydrate, fat, and protein metabolism and leads into chronic complications from the damage of insulin secretion, insulin sensitivity, or both [1]. This disease can increase the risk of heart disease and stroke. $50 \%$ of diabetes death occurs from cardiovascular disease (especially heart disease and stroke). DM also causes neuropathy, increasing the likelihood of foot ulcers, infections, and amputations.

Although diabetes can be clinically controlled using insulin injections, it does not cure. Inconvenience use and a long time use can lead to numerous clinical complications. A treatment with $\beta$-cell repairment allowed as a long-term treatment in achieving normal blood glucose levels. Therefore, we need a new treatment method to replace the damaged cells and normalize the function of pancreatic $\beta$ cells and eliminate the patient's dependence on diabetes oral drug and insulin.

In Indonesia, eggs have been used as food ingredients because of their complete nutrition. Chicken eggs are a source of nutrients that contain proteins, lipids, vitamins, minerals, and growth factors which are important for embryonic development, such as the basic nutrients that form a chicken's biological function and provide defense factors to protect the embryo from bacterial and viral infections [2]. Fibroblast growth factors (FGF) are responsible for signal stimulation in early cell development processes (such as pattern fixing, proliferation, differentiation, and migration) to form a network [3].

In addition to eggs, tempe, a product of fermented soybean can also be an alternative source of vegetable protein because it has high enough protein content. With this high enough content, fermented soybean is food that is highly recommended to provide a positive effect for health. Fermented soybean also contains flavonoids and phytoestrogens that contain isof1avonoid such as genistein which is very useful to overcome hyperglycemia and to prevent some diabetes complications [4].

Our previous study in 2016 already done a stem cell-based research with given FGF and protein which came from a fish snack. The result of the study is the combination of FGF and protein significantly reduces the glucose level in mice at the $14^{\text {th }}$ day $(\mathrm{p}<0.05)$. Then, our other research about FGF level in fertilized eggs that had been done with a quantitative analysis based on the Enzyme-Linked Immunosorbent Assay method obtained FGF level of 219,006 ng/L. Last but not least, we also studied about the use of FGF and its combination with soybean (Phaseolus radiates) which proved that this combination able to decrease the blood glucose level significantly at $\mathrm{p}<0.05$.

The purpose of our study is to investigate the effect of egg whites powder fertilization with vegetable protein from fermented soybean flour to decrease the blood glucose level and as a repairmen for pancreatic $\beta$-cells that were damaged by alloxan and it is expected to know whether that adult stem cells in pancreatic tissue can differentiate to replace $\beta$-cells or not.

\section{MATERIALS AND METHODS}

Materials

The ingredients used are the fertile eggs (Gallus domesticus), fermented soybean (Glycine max fermented with Rhizopus oligosporus yeast), white mice, $0.5 \%$ Sodium-Carboxymethyl Cellulose (Na-CMC), distilled 
water, standard food for mice, alloxan monohydrate Sigma-Aldrich $®$, $10 \%$ neutral formaldehyde buffer (BNF), and xylol solution.

\section{Methods}

Animal preparation

Female mice (Mus musculus) aged around 2-3 months with an average weight of 20-30 g were collected for 56 samples. Animals used should be acclimatized first for 7 days. All of the mice must be healthy and given enough foods and drinks. Animals were randomly divided into 7 groups in which each group consists of 7 mice.

\section{Test preparation (FGF in egg whites powder)}

Thirty chicken eggs (Gallus domesticus), fertile, not cracked, and taken with care were used for this study, and there should be no excessive shocks. The eggs were put into an incubator that contains fermented soybeans at a temperature of $38-39^{\circ} \mathrm{C}$ for 9 days. In each day, the eggs were turned for twice. The eggs that were cracked with the white part, and the yolk part was separated. Egg whites were made into powders with freeze-drying method then homogenized, shaken with an egg beater manually and then poured onto a Petri dish, then dried with a freeze dryer tool.

\section{Making fermented soybean powder}

Fermented soybeans sliced as small as possible with a thickness of $\pm 1 \mathrm{~cm}$. Then, those were dried in the oven at a temperature of $70^{\circ} \mathrm{C}$ for $\pm 7 \mathrm{~h}$ [5]. After that those were grinded using a blender to form powders/grains of fermented soybean. Furthermore, the finely grounded fermented soybeans were sieved with a size of 100 mesh until homogeneous.

\section{Dosing plan}

The experimental animals were treated with fermented soybean in a dose of $7250 \mathrm{mg} / \mathrm{kg}$ and combined with the 5 dosages variations of egg whites powder at 100,140,200,300, and $425 \mathrm{mg} / \mathrm{kg}$. As the inducer for diabetes in mice, alloxan was given in a dose of $150 \mathrm{mg} / \mathrm{kg}$.

\section{The treatment of animal experiments}

All animal groups except the negative controls received an alloxan induction before the treatment which was administered for 16-18 h. The experimental animals were given standard foods and water for 7 days. The blood glucose levels check-in mice were performed at day 7 with digital glucose (GlukoDr®) measurement for all of the animal groups.

Nearly $0.5 \%$ Na-CMC solution is given to the negative control and positive control group, then the test solutions were administrated orally with prescribed doses to Group 1 until 5 for the next 21 days. Blood glucose levels check were done after $7^{\text {th }}, 14^{\text {th }}$, and $21^{\text {st }}$ day of test preparation and previous mice were served for 6-8 $\mathrm{h}$.

The experimental animals in the test were treated after the blood glucose level check was completed on the $21^{\text {st }}$ day. The animals were treated first with ether; then they were sacrificed with neck dislocation and dissected with surgical scissors so that its pancreas can be taken for histopathology and immunohistochemistry of pancreatic tissue.

\section{Histopathological examination}

The pancreatic tissue was taken and prepared by a fixation process that its immersion is in a $10 \%$ neutral formaldehyde buffer solution, then dehydrated using stratified alcohol and cleaned with xylol. The dehydrated preparation was grown in pre-filled liquid paraffin molds then cooled down in the cold plate. The hardened mold then removed, and the obtained blocks were stored in the refrigerator until it is ready to be cut with a microtome. The preparation in paraffin blocks was being cut using a microtome in a thickness of $5 \mu \mathrm{m}$ to form a ribbon-like and placed on the top of the warm water to prevent it from folding. After that, the preparation was placed on top of the object glass and dried at the room fermented soybean. The preparation then stained with the HematoxylinEosin (HE) and was being observed with an electric microscope.

\section{Immunohistochemical staining}

Immunohistochemical staining was performed to observe the spread of insulin-producing $\beta$-Cells in the pancreatic Langerhans island. The initial step of this staining was rehydration for $3 \mathrm{~min}$. The preparation was immersed in a solution of xylol I, II, and III, absolute I, II, and III, and 95\%, $90 \%, 80 \%$, and $70 \%$ alcohol. The preparation is washed with distilled water (DW), rinsed with 3 phosphate buffer saline (PBS) solution, and given with a border by dacopene marker. In the next step, the preparation was incubated with normal serum for $30 \mathrm{~min}$ and rinsed with PBS solution thrice. Then, the preparation was incubated next with an anti-insulin antibody in the refrigerator for one night and rinsed with PBS solution thrice. The preparation then was also reacted with Envision Kit for 30 min and rinsed with PBS solution thrice. Next, it was visualized using 1,3-diaminobenzidine and washed with DW. The last steps of this staining method were dehydration, clearing, and mounting. The calculation of pancreatic $\beta$-Cells was performed in per field of view at $\times 40$ magnification. Qualitative examination of pancreatic $\beta$-cells in immunohistochemistry. The observation of pancreatic tissue fragments especially in $\beta$-cells stained with immunohistochemistry was done by looking at the population of the $\beta$-cells that were stained and looked brown in color.

\section{Quantitative examination of pancreatic $\beta$-cells on} immunohistochemistry

Calculation of pancreatic $\beta$-cells was performed per-field view at $\times 40$ magnification. The observation of immunohistochemical staining is by calculating the average number of pancreatic $\beta$-cells using the application of the image.

\section{Statistic analysis}

The data analysis used is a statistical test of one-way analysis of variance (ANOVA) and two-way ANOVA. One-way ANOVA is used to compare the number of $\beta$-Cells obtained in each test group and the two-way ANOVA is to compare the difference in the mean of blood glucose levels between the dose group factors and the duration of the observation. The degree of confidence is $95 \%$, and results are said to be significant if $\mathrm{p}<0.05$.

\section{RESULTS AND DISCUSSION}

Dosage of egg whites powder and fermented soybean flour The study used a white sample of fertilized eggs with fermented soybean flour as a source of amino acids. The egg whites were taken from the chicken embryo for 9 days, dried by freeze-drying method so as not to damage the protein and growth factor that was also composed of amino acids. While the fermented soybean was dried using an oven, the fermented soybean ratured at $65^{\circ} \mathrm{C}$ so that the content in the fermented soybean is not damaged. The percentage of shrinkage of egg whites powder obtained was $26.18 \%$, while the percentage of fermented soybean powder shrinkage was $26.97 \%$. Fig. 1 showed egg whites powdery dosage and yellowish-white color, while fermented soybean powder is shaped and brownish-yellow.

\section{Measurement of blood glucose levels during the observation}

This study used alloxan as a chemical induce to damage the pancreatic $\beta$-cells which are resulting in an elevation of blood glucose levels. The

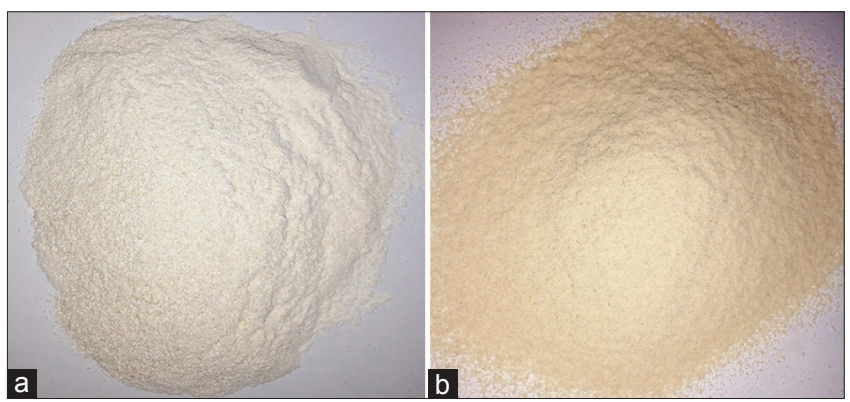

Fig. 1: (a) Egg whites powder with freeze-drying method. (b) Fermented soybean flour with oven method 
function of alloxan is to increase the blood glucose levels because alloxan is selectively toxic against pancreatic $\beta$-cells which produce insulin so that the accumulations of alloxan, in particular, were passed through glucose transporter or GLUT-2 [6]. The diabetogenic effect is antagonistic with glutathione reacting with the $\mathrm{SH}$ group [7]. Alloxan induction can cause hyperglycemia in mice because alloxan in the body system will give an experience of oxidation in metabolism and a produce reduction of free radical. These free radicals can cause damage to the Langerhans $\beta$-Cells, and as result, insulin cannot be produced, causing hyperglycemia or called DM. Blood glucose measurements were performed on days 0 , 7,14 , and 21 . The parameters observed were blood glucose values that were affected by the type of treatment and time. Type of the treatment or group that was observed is which in the test group that gives effect in decreasing blood glucose level and for time seen with duration of giving then expected effect in decreasing blood glucose level better. The observation of blood glucose levels in mice showed an increasing and also decreasing effect (Fig. 2). The test results based on two-way ANOVA statistics showed that there was an interaction effect between treatment group cohort and duration of treatment in blood glucose $(\mathrm{mg} / \mathrm{dl})(\mathrm{p}=0.000<0.174)$, treatment group had a significant effect on blood glucose level in the experimental animals ( $p=0.000<0.05)$, and the treatment time also had a significant effect with the blood glucose level of the experimental animals $(\mathrm{p}=0.000<0.05)$.

\section{Histopathology of the pancreas mice}

Histopathologic examination using HE-staining consists of two color components, named HE. Hematoxylin is an alkaline blue dye that can color the acid cell nuclei, while eosin is an acidic red substance that can color the basic cytoplasm [8]. The observed parameters of HE-staining on pancreatic preparations are common morphology of Langerhans Island pancreas [9]. However, HE-staining cannot distinguish the endocrine cells located on the island of Langerhans. The types of pancreatic endocrine cells can only be distinguished by immunohistochemical techniques [10].

The histopathological morphology of the Langerhans island pancreas in mice is seen microscopically with 400 times magnification. The histopathological features of the pancreatic tissue of the mice in the negative control group indicated normal form of the regularity of the arrangement of endocrine cells that spread in the island of Langerhans with uniform cell shape and cytoplasmic size is visibly proportional to the core size and unchanged (normal).

The histopathological features of the pancreatic tissue of the mice in the positive control group indicated the occurrence of necrosis on Langerhans island which marked by the presence of empty spaces on the tissues [16]. In addition, there are some cells that undergo size changes such as the cells become smaller, nuclei cell break, and nuclei cell disappear. This happens because the induction of alloxan that causes external stimuli exceeds the capacity of the cell to adapt and causes the injury of the cell, then the cell dies. This pathological cell death is called apoptosis [11]

The histopathological features of pancreatic tissue from Group 5 mice showed better results from the positive control group characterized by the apparent uniformity of the shape and size of pancreatic endocrine cells that spread in the Langerhans region, but not yet compact and intact as negative controls (Fig. 3).

The histopathological picture of pancreatic tissue of group 6 mice showed that endocrine cells have begun to regenerate and approach its normal form. Starting regularly the arrangement of endocrine cells that spread on the island of Langerhans signifies the occurrence of cell repairs of $\beta$-cells. $\beta$-Cells repairmen caused insulin to reproduced and worked to insert the blood glucose into the cells to serve as cell's energy source. Better form and proliferation of the $\beta$-cells in the test preparation might be happen due to the active stem cells in pancreatic tissue after the growth factors were induced, one of it is the FGF which can be found in the white egg embryo that 9 days aged.

In a previous study, FGF was found to be bound to proteins present in chicken embryos from the developmental stage to chicks. The amount of FGF present in the entire embryo tissue at 2-6 days is constant. However, the number decreases as you enter the age of 6-7 days and

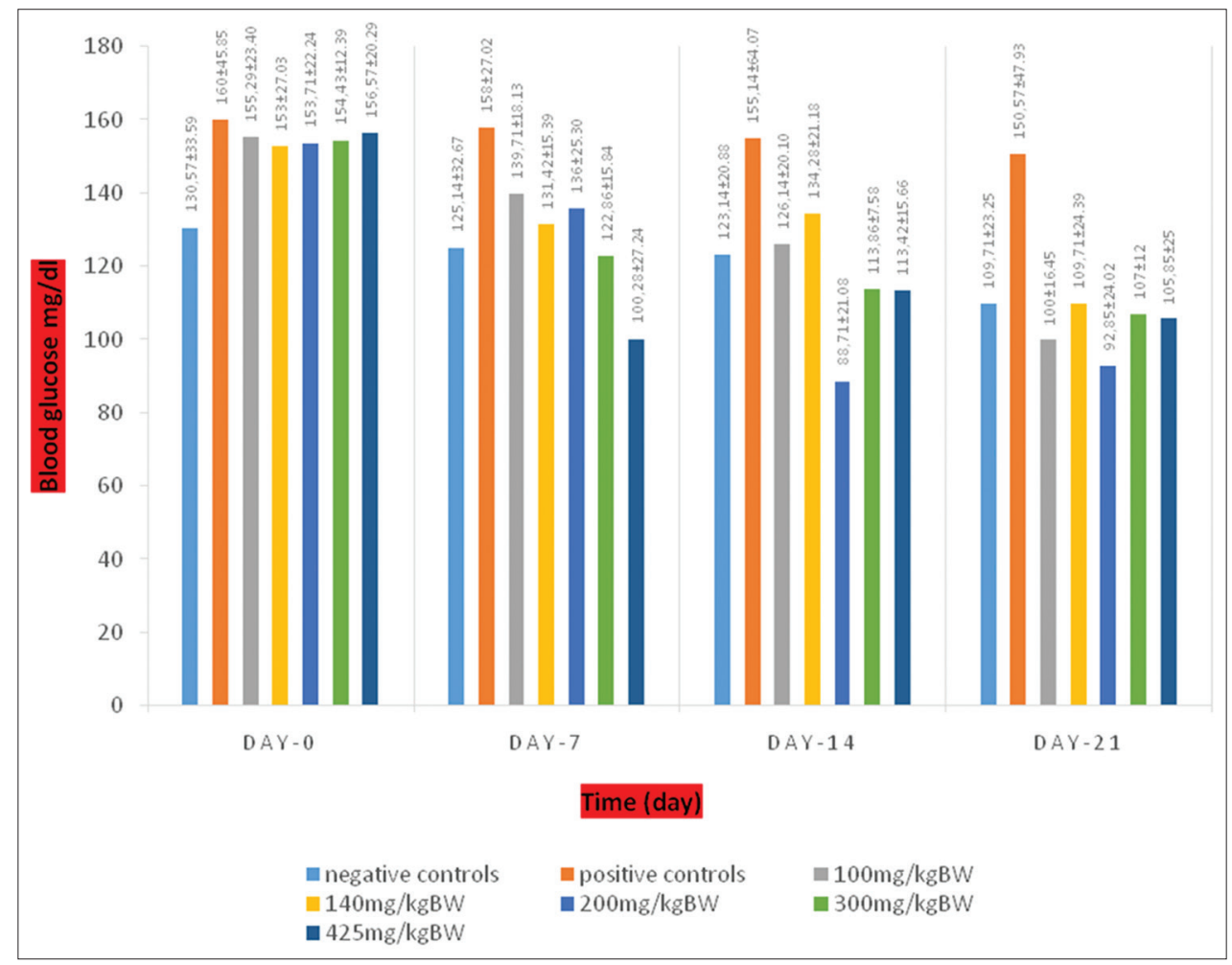

Fig. 2: Average blood glucose levels of mice for 21 days of study and observed every day to $0,7,14$, and 21 
increases again when the embryo is 9-13 days old. The decrease and increase in FGF levels indicate a change in the FGF arrangement for the development of certain organs. The increasing amount of FGF is stored in the extracellular matrix and will be released at any time during trauma or illness.

In addition, the content of soybean which works synergistically to lower the blood glucose levels is protein, isoflavones, fiber, and low glycemic index [14]. The content of isoflavones in the form of genistein can inhibit $\alpha$-glucosidase that plays a role in some metabolic abnormalities such as DM [15]. Fiber can affect blood glucose levels because it is slowing the absorption of glucose which affecting the decrease in glucose. The low fermented soybean glycemic index makes the body's blood glucose response low so that glucose levels are relatively small [12].

\section{Immunohistochemical pancreatic $\boldsymbol{\beta}$-cells features}

Immunohistochemical tests provide the image results using a $\times 40$ magnification microscope by observing the brown $\beta$-cells on Langerhans island because the $\beta$-cells that produce insulin are present in the endocrine cells of Langerhans island. In each group shows the number of different $\beta$-cells. In the negative controls in which normal $\beta$-cells of the pancreas beta tissue do not have cellular damage where damage such as karioreksis occurrence (rupture of the core membrane and core fragmentation), karyolysis (chronic lysis of chromatin), or pynosis (clumping of core contents), so the production of insulin is also normal. In the positive controls in which the beta-pancreatic betacell tissue of the alloxan-induced diabetes indicates that pancreatic $\beta$-Cells are already damaged. The edges of the $\beta$-Cells are still higher
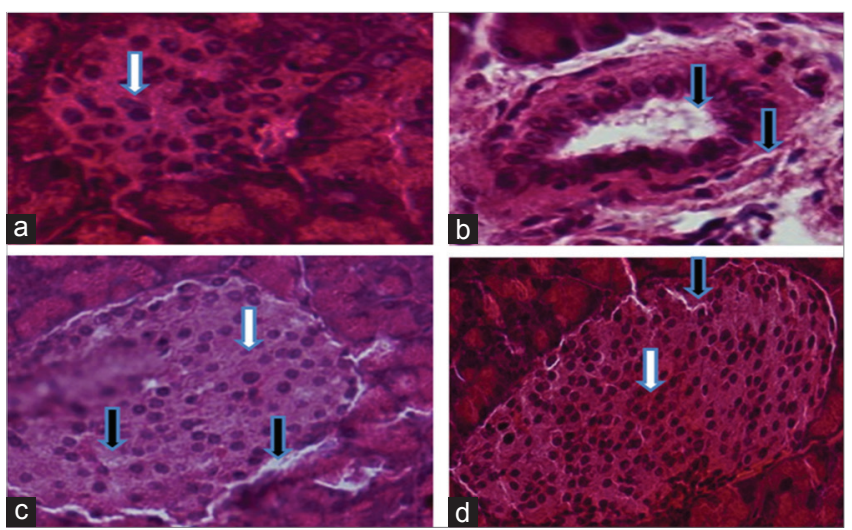

Fig. 3: Microscopic photos of Langerhans island pancreas mice using Hematoxylin-Eosin staining and $\times 400$ magnification. (a): Negative control, (b): Positive control, (c): Group Dose 5, (d): Group dose 6, sign is normal endocrine cell, sign is degenerate endocrine cell

Table 1: Calculation of mean and standard deviation

\begin{tabular}{ll}
\hline Intervention & Mean \pm SD \\
\hline Positive control & $58.10 \pm 1.365$ \\
Negative control & $65.28 \pm 2.771$ \\
$425 \mathrm{mg} / \mathrm{kg}$ dose & $54.58 \pm 1.575$ \\
\hline
\end{tabular}

Values are reffered as mean \pm SD, SD: Standard deviation but in the middle were already damaged cells. The damage indicates that pancreatic $\beta$-Cells on Langerhans island that produce insulin cause a production reduction of insulin. The destruction of pancreatic $\beta$-cells was caused by the administration of alloxan. In beta-induced pancreatic $\beta$-tissue cells mice were fed egg whites fertilized in a dose of $425 \mathrm{mg} / \mathrm{kg}$ and fermented soybean suspension in a dose of $7250 \mathrm{mg} / \mathrm{kg}$ showed that the brown $\beta$-cell by immunohistochemistry had begun to increase slightly. When compared with a positive control group, it can be said to have undergone cell recovery due to damage caused by alloxan administration. Hence, the production of insulin in this group increased compared to the positive control group because of pancreatic $\beta$-cells that have improved. Better formation and $\beta$-cells proliferation in test preparations may be due to active stem cells in pancreatic tissue after induced FGF found in egg white embryo 9 days aged as well as provision of isoflavones genistein can modulate insulin secretion through cAMP/PKA activation mechanisms and increased activation of ERP1/2 in intracellular cAMP, which causes insulin secretion increases [13]. Immunohistochemical staining on the Langerhans island pancreatic tissue of mice exhibits brown $\beta$-Cells. (a) Negative control, (b) positive control, (c) dose group $425 \mathrm{mg} / \mathrm{kg}$, dark brown $\beta$-Cells show much insulin (black arrow), $\beta$-Cells damaged (white arrow) (Fig. 3).

Quantitative analysis of pancreatic $\beta$ Cells in immunohistochemical Quantitative analysis of $\beta$-cells was calculated from the percent area of pancreatic $\beta$-cells using the ImageJ application. ImageJ or image processor helps to measure the size of microbubbles images and analyzes so as to produce a percent value area of pancreatic $\beta$-cells and then calculated mean and standard deviation (SD) from percent area of pancreatic $\beta$-cells. Quantitative calculations were continued with statistical analysis which used one-way ANOVA test to compare the mean values obtained from the measurement of more than two samples. There were three samples used in positive control, negative control, and a dose group of $425 \mathrm{mg} / \mathrm{kg}$. The results in ANOVA calculation showed a Sig value of 0,000 $(<0.05)$, which means the mean percentage of pancreatic $\beta$-cells area for three different treatments. Based on the Duncan test, it can be argued that the test group is divided into two subsets where the first subset of control is positive and the dose group of $425 \mathrm{mg} / \mathrm{kg}$ with Sig. $=0.237(>0.05)$ means there is no difference of percent of $\beta$-cells area between positive control group and dose group of $425 \mathrm{mg} / \mathrm{kg}$, so it can be concluded that the combination of egg whites powder and fermented soybean powder with a dose of $425 \mathrm{mg} / \mathrm{kg}$ cannot repair the damaged tissue of pancreatic that induced with alloxan because there was no significant difference between the positive control group and the dose group of $425 \mathrm{mg} / \mathrm{kg}$. The result showed in Tables 1 and 2 .

\section{CONCLUSION}

The results presented in this study showed that the numerous dosages of egg whites powder at 100,140, 200,300, and $425 \mathrm{mg} / \mathrm{kg}$ combined with fermented soybean in a dose of $7250 \mathrm{mg} / \mathrm{kg}$ decreased the blood glucose levels significantly in positive control with $\mathrm{p}<0.05$ and the occurrence of the Langerhans island cells was nearly normal after a histopathological test. However, in the qualitative analysis, the color of the immunohistochemical in the picture is not very clear, so the quantitative analysis on the dose of egg whites powder at $425 \mathrm{mg} / \mathrm{kg}$ and soybean at $7250 \mathrm{mg} / \mathrm{kg}$ are still not able to go under normal conditions. This might be caused by the free-radical alloxan which still working at the $\beta$-Cells.

Table 2: Average percentage of pancreatic $\beta$-cells area

\begin{tabular}{|c|c|c|c|c|c|c|c|}
\hline \multirow{2}{*}{$\begin{array}{l}\text { Intervention } \\
\text { Positive control }\end{array}$} & \multicolumn{6}{|c|}{ Percentage (\%) of pancreatic $\beta$-Cells area in Langerhans island } & \multirow{2}{*}{$\begin{array}{l}\text { Mean } \pm \text { SD } \\
58.1 \pm 1.36\end{array}$} \\
\hline & 59.75 & 56.87 & 56.31 & 58.67 & 59.29 & 57.756 & \\
\hline Negative control & 61.56 & 67.72 & 66.29 & 61.97 & 67.40 & 66.721 & $65.2 \pm 2.7$ \\
\hline $425 \mathrm{mg} / \mathrm{kg}$ dose & 53.86 & 55.75 & 52.19 & 54.28 & 56.75 & 54.679 & $54.58 \pm 1.57^{\circ}$ \\
\hline
\end{tabular}

Values are referred as mean, SD, SD: Standard deviation 


\section{ACKNOWLEDGMENT}

The authors are thankful to Andalas University, Padang, West Sumatera, which have provided facilities for funding support and the implementation of this research.

\section{AUTHOR'S CONTRIBUTION}

All authors worked to do this manuscript. Dianty DwiWahyuni, Fadhilah Afifi collected data, wrote a final manuscript, and Dwisari Dillasamolaediting of the manuscript. DeddyAlmasdy, RoslindaRasyid, wrote the first draft and collected data, and Surya Dharma finishing of the manuscript. All authors read and approved the final manuscript.

\section{CONFLICTS OF INTEREST}

All the authors have no conflicts of interest.

\section{REFERENCES}

1. Dipiro JT, Wells BG, Scwinghammer TL, Hamilton CW. Pharmacotherapy Handbook. $7^{\text {th }}$ ed. New York (USA): McGraw-Hill Education; 2009.

2. Kovacs NJ, Philips M, Mine Y. Advance in the value of eggs and egg components for human health. Journal Agra Food Chem 2005;53:8421-31.

3. Thisse B, Thisse C. Functions and regulations of fibroblast growth factor signaling during embryonic development. Dev Biol 2005;287:390-402.
4. Kwon DY, James W $3^{\text {rd }}$, Daily, Kim HJ, Park S. Antidiabetic effects of fermented soybean products on Type 2 diabetes. Nutr Res 2010;30:8-10.

5. Omosebi MO, Otunola ET. Preliminary studies on fermented soybean flour produces from three different rhizopus species. Int J Biotechnol Food Sci 2013;1:90-6.

6. Lenzen S. The mechanisms of alloxan and streptozotocin induced diabetes. Diabetologia 2008;51:216-26.

7. Gehad AA, Dalia OS, Sally AE, Manal B. Effect of combination of two plant extracts on diabetes mellitus. Int J Pharm Pharm Sci 2018;1:49-52.

8. Jose D, Harindran JA. Effect of combination of two plant extracts on diabetes mellitus. Int J Pharm Pharm Sci 2018;10:49-52.

9. Suharmiati S. Bioactivity examination antidiabetes mellitus medicinal plant. World Med Mirror 2003;140:23-7.

10. Mescher LA. Basic Histology Janquiera Text and Atlas. $12^{\text {th }}$ ed. Jakarta (Indonesia): Penerbit Buku Kedokteran EGC; 2011.

11. Sudiana IK. Basic Technology of Tissue and Immunohistochemical. Jakarta (Indonesia): Sagung Seto; 2015.

12. Confer AW, Panciera RJ. Thomson's Special Veterinary Pathology. $2^{\text {nd }}$ ed. United States America: Mosby; 1995.

13. Damjanov I. Text Books and Colored Atlas Histopathology. Jakarta (Indonesia): EGC Medical Book Publishers; 2009.

14. Rahadiyanti A. Effect of Soybean Tempe on Pre Diabetes Blood Glucose. Review Article. 2015;5-6.

15. Liu D, Zhen W, Yang Z, Carter JD, Reynolds KA. Genistein acutely stimulates insulin secretion in pancreatic beta-cells through a camp- dependent protein kinase pathway. Diabetes 2006;55:1043-50.

16. Chidambaranathan RS, Syed HP. Anti-hyperglycemic effect of hydroalcoholic extract of thunbergiafragrans in experimental diabetes. Int $\mathbf{J}$ Curr Pharm Res 2015;7:38-42. 